\title{
A NEW APPROACH TO AGENCY FINANCING: NEW ENGLAND POWER AND CLAY BROADCASTING
}

As the cost of government has risen in recent years, Congress has shown increasing interest in making the various federal agencies as nearly self-supporting as possible. ${ }^{1}$ In 1952, an amendment to an appropriations statute directed the agencies to consider possible new funding systems, and authorized the imposition of "user charges" on the recipients of agency services. ${ }^{2}$ For almost two decades, the Congressional directive went largely unnoticed, and the agencies continued to subsist almost entirely on funds from general appropriations. In 1969, however, Congressional pressure caused the Federal Communications Commission to increase sharply user charges on the broadcast industry, and the Federal Power Commission soon raised its fee schedules. ${ }^{4}$ The new rates were promptly challenged in the courts. In 1972, the Court of Appeals for the District of Columbia Circuit struck down the FPC fee schedule, ${ }^{5}$ only a month after the Court of Appeals for the Fifth Circuit had approved the FCC charges. ${ }^{6}$ The ensuing discussion will examine the conceptual and statutory basis of the agencies' user charges and will consider the legality and desirability of this form of public financing.

\section{Statutory Authority for Allocating Cost to Private Parties}

The rate schedules instituted by the agencies are based on the

1. See, e.g., H.R. REP. No. 649, 91st Cong., 1st Sess. 6 (1969); H.R. REP. No. 1348, 90th Cong., 2d Sess. 4 (1968); S. REP. No. 949, 91st Cong., 2d Sess. 5 (1970); S. REP. No. 1375, 90th Cong., 2d Sess. 3 (1968); Hearings on Appropriations for 1971 Before the Subcomm. on Independent Offices and Department of Housing and Urban Development of the House Comm. on Appropriations, 91st Cong., 2d Sess., pt. 2, at 951 (1970).

2. Act of Aug. 31, 1951, Pub. L. No. 137, ch. 376, tit. V, § 501, 65 Stat. 290 (codified at 31 U.S.C. $\$ 483$ (a) (1970)).

3. 47 C.F.R. $\$ \$ 1.1111-1.1120$ (1972).

4. 18 C.F.R. $\S \$ 36,159$ (1972).

5. New England Power Co. v. FPC, 467 F.2d 425 (D.C. Cir. 1972), petition for cert. filed, 41 U.S.L.W. 3477 (U.S. Mar. 6, 1973) (No. 72-1162).

6. Clay Broadcasting Corp. v. United States, 464 F.2d 1313 (5th Cir. 1972), petition for cert. filed, 41 U.S.L.W. 3378 (U.S. Jan. 2, 1973) (No. 72-948). 
theory of the user tax-that is, one who receives a governmental service should pay fair value for it. The concept is hardly novel. Two obvious examples are postage stamps and toll bridges. Special problems arise, however, when the principle is applied to the services performed by regulatory agencies. By their nature, such bodies serve both an imdividual industry and the public generally, ${ }^{7}$ and it is often difficult to determine which of these frequently adverse groups is the actual beneficiary of a particular agency action. ${ }^{8}$ Moreover, agencies often do not confer benefits uniformly within a single industry. ${ }^{9}$ In the face of the practical difficulty of accurately assessing the value of services and benefits, and of ascertaining the true beneficiary, the traditional solution has been to charge these costs to the public at large through the general tax and appropriation framework of government financing. ${ }^{10}$ It is this approach which Congress has sought to change.

In 1952, the burgeoning costs of the federal administrative agencies spurred Congressional concern that the government was "not receiving full return from many of the services which it renders to special beneficiaries." 11 The Subcommittee on Independent Offices and Department of Housing and Urban Developinent of the House Committee on Appropriations noted that although the fees charged by some agencies were limited by statute, other agencies, even though subject to no such restriction, were imposing no charges

7. See, e.g., 47 U.S.C. $\$ 151$ (1970) (FCC); 42 U.S.C. $\$ 4321$ (1970) (EPA).

8. For example, the Interstate Commerce Commission charges common carriers up to $\$ 700$ for its consideration of various applications. 49 C.F.R. $\$ 1002.2$ (d) (1972). Among these applications are requests to construct or abandon a portion of a railway line and consolidation petitions of two or more carriers. In considering these applications, the Commission must weigh both the public interest and the need of the carrier for the specific request. See also 14 C.F.R. $\S 389.25$ (1972) (filing fees of the CAB).

9. For example, the company which elects to contest a decision of a federal agency through judicial review will have to bear the expense of litigation; yct, the final determination of the issue involved will be of substantial benefit to other members of the industry who can profit from the precedential effects of a favorable ruling without incurring the attendant costs. Ironically, New England Power Co. v. FPC, 467 F.2d 425 (D.C. Cir. 1972), is a case in point.

10. The Department of Defense and the Department of Labor present good examples of the application of this principle. Both charge minimal fees for routine administrative services. 32 C.F.R. $\$ 288$ (1972) (Dep't of Defense); 29 C.F.R. $\$ 70.6$ (1972) (Dep't of Labor). The bulk of their work, however, involves such a broad range of subjects that the costs of running these departments cannot be assessed against any particular group of persons.

11. H.R. REP. No. 384, 82d Cong., 1st Sess. 2 (1952). 
whatever. The subcommittee also found that those agencies which did levy user fees often failed to receive adequate compensation because of the outdated formulae employed in computing costs. ${ }^{12}$ As a result, Congress attached a rider to a 1952 appropriations act, Title V, which urged each federal agency to reevaluate its fee structure. ${ }^{13}$ The statute further authorized the establishment of new rates calculated to make the agency "self-sustaining to the full extent possible."14 The statute stated:

It is the sense of the Congress that any work, service, publication, report, document, bencfit, privilege, authority, use, franchise, license, permit, certificate, registration or similar thing of value or utility performed, furnished, provided, granted, prepared, or issued by any Federal agency . . . to or for any person . . . shall be selfsustaining to the full extent possible, and the head of each Federal agency is authorized ... to prescribe therefor such fee, charge, or price, if any, as he shall determine .. . to be fair and equitable taking into consideration direct and indirect cost to the Government, value to the recipient, public policy or interest served, and other pertinent facts ....15

Notably, Title $\mathrm{V}$ does not compel any agency to institute user charges; $;^{10}$ furthermore, it explicitly prohibits an agency whose fees are restricted by a pre-existing statute from utilizing the provision as justification for increasing its fees. ${ }^{17}$ Except for this limitation, however, full discretion is granted to the head of each administrative agency to impose fees that are "fair and equitable."18

On its face, Title $V$ seems to authorize the introduction of charges designed to recover the entire cost of regulating an industry as well as minimal charges for relatively minor and specific services. $^{19}$ In 1959, the Bureau of the Budget directed a circular to the

12. Id.

13. Act of Aug. 31, 1951, Pub. L. No. 137, ch. 376, tit. V, $\S 501$, 65 Stat. 290 (codified at 31 U.S.C. $\$ 483$ (a) (1970) ).

14. Id.

15. Id. (emphasis added).

16. The statute provides that "the head of each Federal agency is authorized by regulation," id. (emphasis added) to impose fees for the services enumerated in note 24 infra. See Aeronautical Radio, Inc. v. United States, 335 F.2d 304, 307 (7th Cir. 1964), cert. denied, 379 U.S. 966 (1965).

17. 31 U.S.C. $\$ 483$ (a) (1970) which provides:

[N]othing contained in this section shall repeal or modify existing statutes prohibiting the collection, fixing the amount, or directing the disposition of any fee, charge or price. . . .

18. Id.

19. FCC Commissioner Ford dissented from the adoption of the fee schedule 
various executive departments, setting forth standards for implementing Title $\mathrm{V} .{ }^{20}$ The guidelines provided several preconditions for the imposition of user charges: the service must be a "special benefit,"21 its recipient must be identifiable, it must be capable of quantitative measurement, and it must be conferred on a recipient imdividually, rather than as part of a service provided for the public generally. ${ }^{22}$ The circular further stated that the "maximum fee for a special service will be governed by its total cost and not by the value of the service to the recipient."23 These rather restrictive standards for levying user cliarges are still followed by most federal agencies. ${ }^{24}$

later challenged in Aeronautical Radio, Inc. v. United States, 335 F.2d 304 (7th Cir. 1964). The Commissioner echoed the objections of the American Bar Association that Title $V$ was "too broad and generalizcd to provide a satisfactory basis for instituting so fundamental a change in this agency's methods of operation." Establishment of Fees for the Commission's Licensing and Regulatory Activities, 34 F.C.C. 811, 827-28 (1963) (dissenting opinion).

20. Bureau of the Budget Circular No. A-25 (Sept. 23, 1959), reprinted in part in New England Power Co. v. FPC, 467 F.2d 425, 428 (D.C. Cir. 1972).

21. More specifically, a "special benefit" was stated to accrue when the governmentally provided service:

(a) Enables the beneficiary to obtain more immediate or substantial gams or values (which nay or may not be measurable in monetary terms) than those which accrue to the general public (e.g., receiving a patent, crop insurance, or a liccnse to carry on a specific business); or

(b) Provides business stability or assures public confidence in the business activity of the beneficiary (e.g., certificates of necessity and convenience for airline routes, or safety inspections of craft); or

(c) Is performed at the request of the recipient and is above and beyond the services regularly received by other members of the same industry or group, or of the general public .....

Bureau of the Budget Circular No. A-25 (Sept. 23, 1959), quoted in 467 F.2d at 428.

22. $I d$.

23. Bureau of the Budget Circular No. A-25 (Sept. 23, 1959), quoted in Clay Broadcasting Corp. v. United States, 464 F.2d 1313, 1317 (5th Cir. 1972).

24. The fees of most federal agencies today fall into two general categories: fees for routine administrative services and filing fees. The following fees are expressly based on the guidelines of Bureau of the Budget Circular No. A-25: $\mathrm{CAB}$ charges for copying documents, certifying the copics, and making available certain publications, 14 C.F.R. $\$ 389$ (1972); CAB fees for various applications ranging from $\$ 0$ to $\$ 25,000$, id. $\$ 389.25$; Department of Defense copying fees, as well as charges for the use of the Department's photos and motion pictures, 32 C.F.R. $\$ 288.10$ (1972); Department of Defense charge of $\$ 125$ to review an application for authorization to solicit members of the military services to purchase life insurance on U.S. military installations in foreign areas, id.; Department of Labor clerical service fees, 29 C.F.R. $\$ 70.6$ (1972).

The following fees do not specifically rely on Budget Circular A-25, but they basically follow the same pattern as those enumerated above: EPA fees for copying 
Since 1968, however, the Subcommittee on Independent Offices and Department of Housing and Urban Development of the House Committee on Appropriations and the Subcommittee on Independent Offices of the Senate Committee on Appropriations have taken a position on the proper use of Title $\mathrm{V}$ which implicitly rejects the Bureau of the Budget interpretation as overly narrow. ${ }^{25}$ As has been noted, ${ }^{26}$ the FCC and FPC, in promulgating new fee schedules, accepted the Congressional viewpoint.

\section{Minimal Fees for Routine Administrattve Services}

The most obvious application of Title $\mathrm{V}$ has been to the routine administrative services performed for private parties by federal einployees. ${ }^{27}$ Typical examples are the searching and copying of records and the notarization of documents, for which the Department of Defense and the Federal Aviation Administration began charging nominal fees in $1962 .{ }^{28}$ In that year, the FAA also established rates for the use of its communications network by private parties. ${ }^{29}$ Since that time, virtually all federal agencies have imposed fees for such routine services pursuant to Title V. ${ }^{30}$

and searching its records based on the fee schedule of the Office of Public Affairs, 49 C.F.R. $\$ 1002$ (1972); 40 C.F.R. $\S 2.111$ (1972); SBA copying fees, 13 C.F.R. $\S 102.6$ (1972); VA copying fees, 38 C.F.R. $\$ 1.526,1.555$ (1972); FDA drug certification fees, 21 C.F.R. $\$ 146.8$ (1972); ICC application fees, 49 C.F.R. $\S 1002.2$ (1972).

The AEC charges a very substantial fee at four stages of its regulation. 10 C.F.R. $\$ 170.12$ (1972). Fees are cliarged on the basis of the type of facility involved (1) when an apphication for a construction permit is signed; (2) when the construction permit is granted; (3) when an operator's license is issued; (4) yearly thereafter. The last category of fees resembles the annual fees assessed by the FCC, 47 C.F.R. $\$ 1.1111$ (1972), especially those charged to licensees.

25. A conference committee of the House and Senate Committees on Appropriations made the following comment:

The Committee of conference is agreed that the fee structure for the Commission should be adjusted to fully support all its activities so the taxpayers will not be required to bear any part of the load in view of the profits regulated by this agency. H.R. REP. No. 649, supra note 1 , at 6 .

26. See notes 3-4 supra and accompanying text.

27. See note 24 supra.

28. 32 C.F.R. $\S 288$ (1972). For a discussion of the reasoning of the Department of Defense in establishing these fees, see 27 Fed. Reg. 401 (1962). The FAA fees are promulgated in 14 C.F.R. $\S 187$ (1972). The fees increased on a varying scale up to $\$ 2.00$ for making duplicate originals.

29. 14 C.F.R. $\$ 189$ (1972). Distress and safety messages were sent free of charge while all others were assessed at the rate of $\$ .25$ for 10 words. The fees were first set out in 27 Fed. Reg. 4955 (1962).

30. E.g., 32 C.F.R. $\$ 1606.57$ (1972). A draft board may charge a registrant $\$ 1$ per page to copy his draft file, or, in the alternative, $\$ 5$ per hour to monitor 


\section{Substantial Fees for TANGible Benefits ConferRed Upon a SPECIAL Benefictary}

The language of Title $\mathrm{V}$ allows the imposition of fees for "any work, service publication, report, document, benefit, privilege, authority, use, franchise, license, permit, certificate, registration, or similar thing of value or utility." 31 This provision lias been interpreted by various agencies to authorize assessing costs of testing a new drug, ${ }^{32}$ considering an interstate carrier's request for a rate increase, ${ }^{33}$ and processing an airline's application to change a route. ${ }^{34}$ In each of these examples, the service provided is likely to involve many einployees and the costs inay not easily be calculated. ${ }^{35}$ The statute is silent as to whether the agency inust establish the exact dollar value of the services provided to the recipient.

One of the first federal agencies to impose substantial fees on the recipients of its services was the FCC, ${ }^{36}$ which in 1963 instituted a flat-fee schedule for each of the several categories of license applications. ${ }^{37}$ The agency admitted that such an approach could not

the file while the registrant himself copies it. These charges have been sustained as authorized by Title V. Reinoehl v. Hershey, 426 F.2d 815 (9th Cir. 1970). See note 24 supra.

31. 31 U.S.C. $\S 483(\mathrm{a})(1970)$.

32. 21 C.F.R. $\$ 146.8$ (1972).

33. 49 C.F.R $\$ 1002.2$ (1972).

34. 14 C.F.R. \& 389.25 (1972).

Although services of this nature may be "routine" to the performing agency, the cost to the Government differs markedly from the also "routine" clerical services offered by many agencies. See note 24 supra.

35. As the service becomes more complex, it will require the work of more agency employees to perform it. Often several employees will be involved on an application at the same time, and unless the agency provides an accounting ledger to each employee to "bill" each application, the exact amount (and therefore cost) of the service will remain unknown. Furthermore, if, based on staff studies, the agency proinulgates general guidelines and requirements applicable to a specific category of licensees or applicants, it would be extremely difficult to apportion precisely the costs entailed in formulating those rules to individual parties.

36. See Establishment of Fees for the Commission's Licensing and Regulatory Activities, 34 F.C.C. 811 (1963).

The fee schedule was the result of a study of FCC operations. This study entailed a breakdown by departments of the cost of services rendered to various categories of license applicants. Cf. Aeronautical Radio, Inc. v. United States, 335 F.2d 304, 310 (7th Cir. 1965).

37. In 1969, administrative costs were broken down into the following categories: Broadcast, 38.8\%; Cable Television, 4.6\%; Chief Engineer, 1.3\%; Common Carrier, 18.6\%; Field Engineering, 5.2\%; Safety and Special Radio, 31.5\%. Amendment of Subpart $\mathrm{G}$ of Part 1 of the Commission's Rules Relating to the Schedule of Fees, 23 F.C.C.2d 880, 882 (1970). 
accurately reflect the cost to the government of processing any individual application. ${ }^{38}$ It contended, however, that ease of administration justified the uniform charges, ${ }^{39}$ and noted as well that the value of the licenses granted greatly exceeded the FCC's application fees. ${ }^{40}$

The broadcast industry immediately challenged the agency's fee schedule, arguing, in Aeronautical Radio, Inc. v. United States, ${ }^{41}$ that Title $\mathrm{V}$ was an unconstitutional delegation of legislative power. The broadcasters further asserted that even if the statute were held to be a valid delegation, the particular rates established were so arbitrary and unreasonable as to be void. The Seventh Circuit rejected the delegation argument, finding in the statute a standard which, althougli implicit, was sufficient to insulate it against constitutional attack: before imposing any fees, each agency must consider its own particular functions and determine that the imposition of fees would be consonant with the "public policy considerations for which the agency was formed." 42 The court found that the FCC had in fact performed the necessary balancing of its responsibilities to the broadcasting industry and its public purpose generally. ${ }^{43}$ In addition, the court held that the broadcasters had failed to sustain the burden of proving the rate schedules to be unreasonable or arbitrary. ${ }^{44}$ The court appeared to be applying the same balancing test both to the imitial question of whether any fee should be permitted and to the subsequent determination of the appropriate level for such charges. ${ }^{45}$ The court approved the FCC's imposition of flat fees,

38. Establishment of Fees for the Commission's Licensing and Regulatory Activities, 34 F.C.C. 811, 816 (1963).

39. Id.

40. Id. at 817. The Commission noted that especially with respect to the capital needed to construct a radio or television facility, the application fee was "nominal."

41. 335 F.2d 304 (7th Cir. 1964), cert. denied, 379 U.S. 966 (1965).

42. 335 F.2d at 307-08. The court quoted from Yakus v. United States, 321 U.S. 414, 426 (1944): "Only if we could say there is an absence of standards . . . would we be justified in overriding the [congressional] choice of means ...." 335 F.2d at 307.

43. Id. at 307.

44. Id. at $306,308-10$.

45. Although the court clearly envisioned this balancing test as controlling an administrator's initial decision to impose a fee schedule, the test would seem to be equally applicable to the amount an agency could charge for its service. The total cost to the government obviously limits maximum aggregate fees the agency nuay charge, but, even within that limit, if such a fee would adversely affect the substantive regulatory policies of the agency, the standard is violated. See id. at 307, 309. 
observing that to compute precisely the direct and indirect cost of a particular license application would require the use of unrealistically complicated accounting procedures. ${ }^{46}$ The court also dismissed the contention, raised by one of the intervenors, that the disparity between different departments of the FCC in the ratio of user charges to overall costs deunonstrated the Commission's arbitrariness in setting rates. ${ }^{47}$ The goal of making the agency self-sustaining was, according to the court, only one of several criteria to be taken into account. ${ }^{48}$ In any case, the FCC's fees represented so small a percentage of the value of the licenses issued as to render inconsequential the complaint of unequal charges. ${ }^{49}$

The decision in Aeronautical Radio was directed only to filing and application fees. At least in theory, such fees are designed only to recoup the costs of processing the application of a particular person or organization-well within the Bureau of the Budget circular's definition of a "special beneficiary." The case does not reach the more difficult question of whether the statute authorizes an agency to recover its total operating expenses, or whether means other than specific charges for particular agency services might be employed.

Fees Charged to an Industry for the General Bengfits RECEIVED FROM AGENCY Regulation

The FCC rates approved in Aeronautical Radio were not intended to recoup the agency's entire operating $\operatorname{costs}^{51}$ - a result likely

46. Id. at 309 .

47. $I d$. at 310. The court sustained the fees involved in this case despite the fact that the revenue collected by Broadcast Services would be only $8 \%$ of the cost of administering that division, whilo Safety and Special Radio Services would pay $72 \%$ of the costs it engendered.

48. Id.

49. Id. The court did not imply that all "minimal" fees would be authorized by Title V. In this case, the court's use of the word "minimal" was misleading because the term is relative to the amount of profit realized by the broadcast industry. The court implied that the fee imposed could not possibly affect the broadcast industry, and therefore the statutory goals of the FCC were not hindered. See id. The dollar amounts involved for these various applications ranged from $\$ 100$ for an application for a new television station or for renewal of such a station's license, to $\$ 2$ for modification of an amateur's license under the Commission's Safety and Special Radio Services Division. Establishment of Fees for the Commission's Licensing and Regulatory Activities, 34 F.C.C. 811, 825-26 (1963).

50. Bureau of the Budget Circular No. A-25 (Sept. 23, 1959), quoted in New England Power Co. v. FPC, 467 F.2d 425, 428 (D.C. Cir. 1972). See note 21 supra.

51. The fees initially imposed represented about $25 \%$ of FCC appropriations for the fiscal year 1964. Amendment of Subpart G of Part 1 of the Commission's 
to displease Congress. ${ }^{52}$ In 1969 , a conference committee "agreed that the fee structure for the Commission should be adjusted to fully support all its activities so the taxpayer will not be required to bear any part of the load in view of the profits [accruing to the industry] regulated by this agency." costs, the FCC attempted to implement the Congressional directive by three means: ${ }^{54}$ an increase in initial filing fees, ${ }^{55}$ the introduction of a two percent charge on the transfer of any broadcast license, ${ }^{56}$ and the assessment of an "annual fee," geared to a broadcaster's advertising revenue and to the number of the CATV operator's subscribers. ${ }^{57}$ At the same time, charges for license renewal applications were eliminated. ${ }^{58}$ The $\mathrm{FCC}$, in promulgating the new rates, explamed that since the Commission's regulatory structure provided the licensee with benefits far greater than the mere processing of an application, it could rightly assess costs above the administrative expenses clearly attributable to a particular party. ${ }^{59}$ With the introduction of the new rate structure, the FCC became the first agency to attempt to become totally self-sustaining. ${ }^{60}$

Rules Relating to the Schedule of Fees-Notice of Proposed Rulemaking, 21 F.C.C.2d 502, 503 (1970).

52. In its report on appropriations for fiscal 1969, the Subcommittee on Independent Offices and Department of Housing and Urban Development of the House Committee on Appropriations again expressed its concern that agencies were not receiving "sufficient return" for services rendered to "special beneficiaries," citing specifically the multibillion dollar radio and television industry which paid fees which were "negligible in comparison to the value of these franchises." H.R. REP. No. 1348, supra note 1 , at 4 . The FCC was urged to pursue further equitable, upward adjustment of fees to a self-sustaining level for fiscal 1970 and 1971 as well. H.R. REP. No. 316, 91 st Cong., 1st Sess. 7-8 (1969); S. REP. No. 949, supra note 1, at 5 .

53. H.R. REP. No. 649 , supra note 1 , at 6 .

54. Amendment of Subpart $G$ of Part 1 of the Commission's Rules Relating to the Schedule of Fees, 23 F.C.C.2d 880 (1970).

55. 47 C.F.R. $\S \S 1.1111-1.1120$ (1972).

56. $I d . \S 1.1111(\mathrm{a})$.

57. Id. $\$ \S 1.1111(\mathrm{a}), 1.1116(\mathrm{~b})$.

58. Amendment of Subpart $G$ of Part 1 of the Commission's Rules Relating to the Schedule of Fees, 23 F.C.C.2d 890, 891 (1970).

59. For example, in a case which tests a particular application of the "fairness doctrine," all the costs of litigating the issue could, at least in theory, be charged to the particular licensee which contests the doctrine's application. The industry as a whole, however, is going to benefit from a definitive ruling on the question. In inuch the same vein is a consideration of the rule-making procedure; although it may be ouly one hicensee which contests a new rule, the actual beneficiaries are all the licensees in the industry. See note 9 supra.

60. See Cox, The Federal Communications Commission, 11 B.C. IND. \& CoM. L. Rev. 595, 602 (1970). 
Congress, satisfied with the FCC's innovations, ${ }^{01}$ turned its attention to the FPC during the hearings on appropriations for fiscal year $1971 .{ }^{62}$ In response to this legislative attention, the FPC increased its filing fees and introduced an annual fee $e^{63}$-apportioned to the members of the fuel and electric industry on the basis of their yearly sales-to cover all of the agency's costs not met by filing fees. ${ }^{64}$

Representatives of the power and broadcasting industries quickly took their objections to the new fee schedules to court. In New England Power Co. v. FPC ${ }^{65}$ the Court of Appeals for the District of Columbia Circuit considered the new rates with reference to Title $V^{60}$ and also with reference to certain sections of the Natural Gas $\mathrm{Act}^{\mathrm{B7}}$ and the Federal Power $\mathrm{Act}^{\mathrm{B8}}$ (both of which were asserted by the FPC to provide additional authority for the type of fees imposed). ${ }^{69}$ In examining the legislative history of Title V, the court placed great emphasis on a sentence froin the Report of the House Committee on Appropriations in which Congressional concern was stressed in regard to "the services which [the Government] renders to special beneficiaries."70 The court also stressed that the 1959 Bureau of the Budget circular had einphasized that no charges were to be levied for services "when the identification of the ultimate beneficiary is obscure and the service can

61. S. REP. No. 949 , supra note 1 , at 5.

62. Hearings on Appropriations for 1971, supra note 1, at 951.

63. The increases in the filing fees are codified in 18 C.F.R. $\$ \S 36.2,159.1$ (1972); the annual fee was introduced in id. $\$ \$ 36.1,159.2 \mathrm{a}$.

64. Class $A$ and $B$ iurisdictional companies as defined in the Natural Gas Act assume that portion of the cost which reflects the ratio of its jurisdictional gas dehveries for the year as compared with the total of such deliveries made by all jurisdictional companies. 18 C.F.R. $\$ 159.2(a)(1)(a)$ (1972). In addition, an annual reserves added assessment is imposed with each pipeline company which is required to file FPC Form No. 15 paying a tenth of a mill for each Mcf of new reserves certified for a particular calendar year. $I d$. $\$ 159.2 \mathrm{a}(\mathrm{b})$.

Under the Federal Power Act, each jurisdictional electric utility's cost is based on the ratio which its consumption of kilowatt hours bears to the sum of the gross jurisdictional sales unade by all public utilities. Id. $\S 36.1(\mathrm{a})(1)(\mathrm{a})$. In addition, the FPC's cost of administering its "co-ordination and reliability programs" is assessed against each utility in the proportion that its gross revenue bears to the sum of the gross electric revenue of all public utilities. Id. $\S 36.1(\mathrm{~b})(1)(\mathrm{b})$.

65. 467 F.2d 425 (D.C. Cir. 1972), petition for cert. filed, 41 U.S.L.W. 3477 (U.S. Mar. 6, 1973) (No. 72-1162).

66. Id. at 427-30.

67. 15 U.S.C. \& $7170(1970)$.

68. 16 U.S.C. $\& 825(\mathrm{~h})(1970)$.

69. 467 F.2d at $427,430-31$.

70. H.R. ReP. No. 384, supra note 11, at 2. 
be primarily considered as benefitting broadly the general public."'71 The court rejected the FPC's contention that the creation of a favorable economic climate for the power industry rendered any particular member of that industry a "special beneficiary" in the sense intended by' Congress. ${ }^{72}$ In finding that Title $\mathrm{V}$ could not provide legal justification for the Commission's new rate schedule, the court observed that there "is something fundamentally wrong in assessing charges on the basis of benefit to the company when the Commission must benefit the public." ${ }^{33}$ The court went on to reject what it called the FPC's "post hoc patchwork" argument ${ }^{74}$ that a statutory basis could be found elsewhere than in Title V. The sections of the Federal Power Act and Natural Gas Act on which the Commission relied, said the court, in reality merely conferred authority to the FPC to make rules for the implementation of powers granted the agency by Congress. ${ }^{75}$ The court further stated that the Commission's reliance on Aeronautical Radio ${ }^{76}$ was misplaced, as that case had involved specific benefits to a particular recipient. ${ }^{77}$

The FCC's rates were challenged by representatives of the broadcast licensees and of the cable television industry in Clay Broadcasting Corp. v. United States. ${ }^{78}$ As in New England Power, the petitioners argued that the agency lacked authority to impose the rates, and that even if such authority were held to exist, the fees established were unreasonably high. ${ }^{79}$ Both these contentions were rejected by the Court of Appeals for the Fifth Circuit, which approved the new fee schedule in its entirety.

In maimtaining that the FCC had exceeded the bounds of Title $\mathrm{V}$, the broadcast licensees pointed out that the Commission's rates, in the first place, took account only of the value of the license to the recipient rather than the administrative costs to the agency and, in addition, charged the industry alone for agency services performed on behalf of the entire population. ${ }^{80}$ However, the court held that

71. 467 F.2d at 428, quoting Bureau of the Budget Circular No. A-25 (Sept. 23, 1959).

72. 467 F.2d at 429 .

73. Id.

74. Id. at 430 .

75. Id. at $430-31$.

76. 335 F.2d 304 (7th Cir. 1964), cert. denied, 379 U.S. 966 (1965).

77. 467 F.2d at 428 n.9.

78. 464 F.2d 1313 (5th Cir. 1972), petition for cert. filed, 41 U.S.L.W. 3378

(U.S. Jan. 2, 1973) (No. 72-948).

79. 464 F.2d at 1317.

80. Id. 
the Commission had acted properly in taking into account the value of the service. ${ }^{81}$ The Bureau of the Budget circular, it found, did not require an exact calculation of the cost of every service performed, as "such precision would be difficult if not altogether impossible to achieve." 82 The court further declared that the industry's view of the services for which charges were permissible demonstrated a "myopic misconception" of the Commission's role; ${ }^{83}$ the FCC, it said, provided both the exclusive right to a frequency and the market conditions necessary for the broadcaster's prosperity. ${ }^{84}$ Citing Aeronautical Radio, ${ }^{85}$ the court held that the FCC had applied the requisite balancing test in assessing the value, cost, and public policy factors involved in establishing user fees. ${ }^{86}$ The court also found reasonable the Commission's fee of two percent of the consideration paid for the assignment of a license or the transfer of control..$^{87}$

The cable television operators attacked the new rate schedule on several grounds: first, that the delegation to the Commission was inproper; ${ }^{88}$ second, that simce the FCC did not license CATV operators, ${ }^{89}$ no "valuable benefits" were conferred;00 and third, that the rates charged cable operators were an inaccurate reflection of actual costs and disproportionately high. ${ }^{01}$ The court rejected all of these allegations. While it conceded that much of the FCC's regulation of CATV had tended to restrict the industry, it noted that FCC regulations had lielped keep entry into the industry open, and observed also that CATV owed much of its economic value to the Commission's maintenance of a scarcity of broadcast television outlets. ${ }^{22}$ Again citing Aeronautical Radio, the court found the Commission to have balanced the various interests correctly and to have set reasonable rates. ${ }^{.3}$

81. Id. at 1318.

82. Id., quoting Bureau of the Budget Circular No. A-25 (Sept. 23, 1959).

83. 464 F.2d at 1317.

84. Id. at 1318.

85. See notes 41-50 supra and accompanying text.

86. 464 F.2d at 1317-18.

87. Id. at $1318-21$.

88. Id. at 1321 .

89. Id. at 1322; Amendment of Subpart G of Part 1 of the Commission's Rules Relating to the Schedule of Fees, 23 F.C.C.2d 880, 883 (1970).

90. $464 \mathrm{~F} .2 \mathrm{~d}$ at 1321 .

91. Id.

92. Id. at 1322.

93. Id. at 1322-23. 
Clay Broadcasting and New England Power: A Comparison

The decisions of the Fifth Circuit, in Clay Broadcasting, and the District of Columbia Circuit, in New England Power, appear incompatible. The inconsistency may be ascribed largely to the courts' different attitudes toward the Bureau of the Budget circular and to the statute it sought to interpret. The New England Power court devoted most of its brief opinion to a demonstration of the conflict between the FPC's new rate schedule and the standards set forth in the circular. At no time, however, did the court attempt to explain why the Bureau of the Budget's interpretation of the statute should be regarded as bimding. ${ }^{94}$ The Clay Broadcasting court, on the other hand, reached its decision by a searching analysis of Title $\mathrm{V}$ and of applicable case law. The Bureau of the Budget circular was mentioned only once, and in a context which indicated that the court did not consider the circular's view of the statute to be controlling. ${ }^{95}$

Froin this basic disagreement, there follows logically the divergence of the two courts with regard to the interpretation of the type of benefit for which Congress sought to require payment, and to the correct construction of Title V's requirement that the "public policy or interest served"96 by the agency be taken into account. A comparison of the language of Title $V$ with the Bureau of the Budget circular leads inescapably to the conclusion that, in one instance after another, the circular has interpreted Congressional intent with a narrowness contrary to the spirit of the statute, and sometimes contrary to its letter as well. Title V speaks in terms of benefits "to or for any person",; the emphasis on the "special beneficiary" is the creation of the circular. ${ }^{98}$ The statute speaks

94. The court merely stated that "[t]he standards and guidelines for application of Title $V$ have been set forth by the Bureau of the Budget . . ." 467 F.2d at 428 . Although the FPC did argue that the fee schedule was within the terms of the circular, id. at 429, such an argument need not be viewed as an admission by the Commission that it viewed the circular as authoritative.

95. See 464 F.2d at 1317-18. The court was noting that the circular demanded that the maximum fee be governed by governmental cost and not value to recipient, an imterpretation not contrary to the aggregate FCC fee schedule. The court in Clay Broadcasting did not quote the portion of the circular which states that charges may be made "to each identifiable recipient for a measurable unit ... from which he derives a special benefit." Bureau of the Budget Circular No. A-25 (Sept. 23, 1959), quoted in 467 F.2d at 428 (emphasis added). See note 21 supra. 96. 31 U.S.C. $\$ 483$ (a) (1970),

97. Id.

98. Although this term originated in the committee report on Title V, H.R. 
broadly of "taking into consideration direct and indirect cost to the government, value to the recipient, public policy or interest served, and other pertinent facts." cliarges only to an "identifiable recipient for a measurable unit or ainount of Government service,"109 and states that "[t]he maximum fee for a special service will be governed by its total cost and not by the value of the service to the recipient."101

It is arguable that the qualifications placed upon the statute by the circular were reasonable. It is arguable as well that the Congress of 1952 (though obviously not that of 1970) might well have written those provisions imto law, ${ }^{102}$ had it considered the matter at any length. Nevertheless, it seems difficult in the extreme to discern, from what Congress actually did say, any intention of enacting into law, in 1952, the restrictions devised seven years later by the Bureau of the Budget. In this regard, it is submitted, the approach of the Clay Broadcasting court seems clearly preferable to that of the New England Power court. ${ }^{103}$

While the New England Power court may have erred on the side of narrowness in its unquestioning assumption that the circular had the force of law, ${ }^{104}$ the broad interpretation of the statute in the Clay Broadcasting decision raises equally serious problems. In the first place, the rate schedule considered in Clay Broadcasting differed significantly from that approved in Aeronautical Radio. The rates considered in Aeronautical Radio involved a flat licensing fee, equalling to a greater or lesser degree the cost to the $\mathrm{FCC}$ of processing an application. In Clay Broadcasting, on the other hand, the agency was proposing to make the broadcaster pay not only for

REP. No. 384 , supra note 11 , at 2 , there is no explanation as to why it was not incorporated in the statute.

99. 31 U.S.C. $\$ 483$ (a) (1970).

100. Bureau of the Budget Circular No. A-25 (Sept. 23, 1959), quoted in 467 F.2d at 428 .

101. Bureau of the Budget Circular No. A-25 (Sept. 23, 1959), quoted in 464 F.2d at 1317 .

102. See note 98 supra.

103. It might perhaps be argued that the court in New England Power was tacitly incorporating the Bureau of the Budget standards into the statute in order to sustain the validity of an otherwise impermissibly vague law. In view of Aeronautical Radio, however, such a position seems hardly tenable. A strict application of the Aeronautical Radio balancing test, see note 42 supra and accompanying text, would have allowed the New England Power court to strike down the FPC schedule from the outset.

104. See note 94 supra and accompanying text. 
the cost of handling the application, but also, on a pro rata basis geared to earnings, for the carpets and typewriters in the FCC's offices. The effect of this is no longer a simple "user charge," but in fact approacles an ungraduated income tax. This tax was, moreover, imposed without any express Congressional authorization, and indeed without any clear indication that it was the desire of Congress. ${ }^{105}$ Title $V$ speaks of the legislative intent to make the agencies "as self-sustaining as possible," but there is no way to determine whether this phrase was intended to inean "ideally, completely self-sustaining" or "as self-sustaining as possible with regard to identifiable services, while general taxes continue to pay for office equipment." The Clay Broadcasting court saw no difficulty in taking the former position. The New England Power court, on the other hand, recognized the importance of the difference, and found no "clear Congressional mandate" for such a major shift of policy.

The Clay Broadcasting court held that maintenance of a favorable economic climate was a "benefit" within the meaning of the statute, while New England Power held to the contrary on the saine issue. It is submitted that the Clay Broadcasting position ascribes to Title $\mathrm{V}$ a breadth of scope which neither the statute on its face nor the legislative history can justify. In this situation, application of the principle of ejusdem generis would seem to be appropriate: when the statute speaks of charges for "any work, service, publication, report, document, benefit, privilege, authority, use, franchise, license, permit, certificate, registration, or similar things of value," 106 the examples enninerated appear to demonstrate conclusively that "maintenance of a favorable economic climate" was not a "similar thing of value" within the ordinary legal use of the term.

The New England Power court also noted that while the FPC had responsibilities both to the power industry and to the public generally, the new rates would transfer the burden entirely to industry. ${ }^{107}$ While the New England Power court should not have grounded its decision on the Bureau of the Budget circular, the court appears to be correct in its basic conviction that the statute did not dictate or authorize the change in public policy inherent in the new rates and might have reached the same result without reference to

105. The fact that recent expansive statements have been made by congressional committees, see notes 1 \& 25 supra and accompanying text, in no way demonstrates the intent of the 1952 Congress which enacted Title $V$.

106. 31 U.S.C. \$ $483(\mathrm{a})$ (1970).

107. 467 F.2d at 429 . 
the circular. Furthermore, the Clay Broadcasting court, in dismissing the broadcaster's complaint of being overcharged with the observation that the licenses were worth far more than the industry was being obliged to pay, ${ }^{108}$ seeins perilously close to the position that the FCC could, if it wished, set its annual fees at any level below the "fair inarket value" of a year's right to broadcast without special authorization from Congress. Such a view runs counter to the principle that is fundamental to the regulation of the airwaves: that broadcast licenses are to be assigned so as to further the public good, and without regard to recovery or redistribution of the enormous profits likely to be earned.

In summation, it is suggested that the court in Clay Broadcasting was in error in finding that Title V authorized the FCC's new fee schedule, while the New England Power court, despite its mistaken rehance on the Bureau of the Budget circular, was correct in striking down the rates established by the FPC. It is possible, nevertheless, to reconcile the cases at least in part. Each court may have tacitly incorporated into its opinion a policy judgment on the wisdom of naking the particular agency self-sustaining. There are, moreover, arguably sound policy grounds for treating the two agencies differently. The FPC, if it forces the power companies to assume all its costs, causes those costs to be passed on to consumers. Thus, a burden is transferred from the tax funds generally to the particular class of users. How this would affect the distribution of wealth throughout the population would appear impossible of determination without enpirical study, but clearly the costs would not be taken from the profits of the industry. In the case of the FCC, the broadcasters are accumulating quasi-monopoly earnings, without any obligation to use those funds in any particular way. The nature of the redistribution of wealth which would result from forcing the industry to use a sinall fraction of those profits to finance the FCC would seein capable of prediction, and also defensible as a matter of policy.

The problem, finally, may be seen as the imprecision of a statute which attempts to treat similarly two such fundanientally disparate agencies as the FCC and the FPC. If indeed Congress had any thought in 1952 that the agencies should be completely self-sustaining, it seems clear that no thought was given to the redistribution of wealth inherent in such a scheine, or to the difference between a hicens-

108. 464 F.2d at 1318 . 
ing and a rate-setting agency. Policy decisions as significant as those involved in determining who should be taxed to support government agencies should be made in the clearest of terms by Congress. In the interim, it seems inadvisable to allow these determinations to be made by the agencies themselves on the basis of dubious inferences from a hastily and ambiguously drafted expression of Congressional aspirations to frugality. 